\title{
Hakikat Bermain Peran Di Sentra Main Peran Pada Anak Anak Usia Dini
}

\author{
Nur Anisyah \\ Stai Ma'arif Jambi \\ Email: anisyahsuid@yahoo.com
}

\begin{abstract}
Role-playing is a way of mastering learning materials through the development of imagination and student passion. The development and passion of the imagination is performed by students acting as a life or dead figure. This method involves a lot of students and makes them happy to learn. This learning method also has added value, which is to ensure the participation of all students and give the opportunity to cooperate successfully, so that it will cause an impression. Roleplaying is a learning method as a simulated part that is geared towards creating historical events, creating actual events, or events that may arise in the future. Role-playing is one form of learning, where learners are actively involved in playing certain roles. Role-playing is something of a stage in which the player plays a specific role according to the already written play and played for entertainment purposes. Something related to education where the individual plays an imaginative situation in order to help achieve self-understanding, improve skills, demonstrate behavior to others how a person's behaviour or how one should behave. Role-playing is one of the learning tools that develops skills and understanding of the relationship between people by playing the path of parallel situations that occur in the actual life. The Learning Center's role-playing Model focuses on the child in the learning process centered around the play center and when the child is in a circle.
\end{abstract}

Keywords: Role playing, Sentra, early childhood

\begin{abstract}
Abstrak
Bermain peran adalah cara penguasaan bahan-bahan pelajaran melalui pengembangan imajinasi dan penghayatan siswa. Pengembangan dan penghayatan imajinasi tersebut dilakukan oleh siswa dengan memerankan sebagai tokoh bidup atau benda mati. Metode ini banyak melibatkan siswa dan membuat mereka senang belajar. Metode pembelajaran ini juga memiliki nilai tambah, yaitu dapat menjamin partisipasi seluruh siswa dan memberi kesempatan dalam bekerja sama hingga berhasil, sehingga akan menimbulkan kesan. Bermain peran adalah metode pembelajaran sebagai bagian simulasi yang diarabkan untuk mengkreasi peristiwa sejarah, mengkeasi peristiwa-peristiwa aktual, atau kejadian-kejadian yang mungkin muncul pada masa mendatang. Bermain peran adalah salah satu bentuk pembelajaran, dimana peserta didik ikut terlibat aktif memainkan peran - peran tertentu. Bermain peran merupakan sesuatu yang bersifat sandiwara dimana pemain memainkan peran tertentu sesuai dengan lakon yang sudah ditulis dan memainkannya untuk tujuan biburan. Sesuatu yang berkaitan dengan pendidikan di mana individu memerankan situasi yang imajinatif dengan tujuan untuk membantu tercapainya pemabaman diri, meningkatkan keterampilan, menunjuk.kan perilaku kepada orang lain bagaimana perilaku seseorang atau bagaimana seseorang harus bertingkah laku. Bermain peran adalah salah satu alat belajar yang mengembangkan keterampilan dan pengertian mengenai bubungan antar manusia dengan jalan memerankan situasi-situasi yang parallel dengan yang terjadi dalam kehidupan
\end{abstract}

11 | ZURIAH : Jurnal Pendidikan Anak Usia Dini, Vol. 1 No. 1, Mei 2020 
yang sebenarnya. Model pembelajaran sentra main peran berfokus pada anak yang dalam proses pembelajarannya berpusat di sentra bermain dan pada saat anak dalam lingkaran.

\section{Kata Kunci: Bermain Peran, Sentra, Anak Usia Dini}

\section{A. PENDAHULUAN}

Bermain peran memberikan kesempatan kepada anak untuk mengembangkan pengertian mereka tentang dunia sekitarnya melalui peran-peran yang dimainkan dimulai dari lingkungan terdekat mereka yaitu keluarga hingga lingkungan sekitar mereka seperti sekolah, pasar, rumah sakit, kantor pos, kantor pemadam kebakaran, pantai/laut, desa. Manusia sebagai makhluk sosial, manusia harus dapat bersosialisasi dan berkomunikasi dengan individu lain dalam rangka menjalin interaksi sosial dengan sesama manusia. Proses sosialisasi diperlukan untuk mengembangkan sikap atau tingkah laku sosial terhadap individu lain dan aktivitas sosial perlu diajarkan pada anak sedini mungkin, terlebih untuk anak - anak yang mulai memasuki jenjang pendidikan prasekolah, baik itu Taman Kanak - kanak (TK) maupun playgroup. Hal ini dilakukan supaya anak tidak tumbuh menjadi individu antisosial, yaitu individu yang mengetahui harapan kelompok sosial, tetapi dengan sengaja melawan hal tersebut. Akhirnya individu antisosial ini ditolak atau dikucilkan oleh kelompok sosial.

\section{B. KAJIAN TEORI}

\section{Pengertian Bermain Peran}

Bermain peran merupakan salah satu potensi dasar (fitrah islam) yang diberikan oleh Allah kepada setiap manusia. Orang tua, pendidik, dan lingkungan yang akan membentuk kepribadian anak yang paripurna atau tujuan hidup mencari ridho Allah, main peran adalah salah satu cara bagi anak untuk dapat mengembangkan pengendalian diri, perolehan pengetahuan, keterampilan kognisi, sosial emosi, bahasa, daya cipta, rangkaian ingatan, konsep-konsep hubungan kekeluargaan. Penerimaan kosakata, keterampilan pengambilan sudut pandang spasial dan keterampilan sudut pandang afeksi, yang dibutuhkan anak dikehidupan selanjutnya (Bahan Ajar TK Al-Muthmainnah, 2020: 6).

Main peran kadang disebut juga dengan main simbolik, main pura-pura, fantasi, imajinasi atau drama. Anak usia dini suka bermain peran dengan melakukan percobaan melalui berbagai bahan dan peran. Kegiatan bermain peran ini penting karena manusia perlu membangun kemampuan untuk menghadapi suatu keadaan dan menguasai kenyataan tertentu dengan terlebih dahulu melakukan uji coba dan perencanaan. Peran dapat didefinisikan sebagai suatu rangkaian perasaan, ucapan dan tindakan, sebagai suatu pola hubungan unik yang ditunjukkan 
oleh individu dalam hidupnya dipengaruhi oleh persepsi individu terhadap dirinya dan terhadap orang lain. Oleh sebab itu, untuk dapat berperan dengan baik, diperlukan pemahaman terhadap peran pribadi orang lain. Pemahaman tersebut tidak terbatas pada tindakan, tetapi pada faktor penentunya, yakni, perasaan, persepsi dan sikap. Bermain peran berusaha membantu individu untuk memahami perannya sendiri dan peran yang dimainkan orang lain sambil mengerti perasaan, sikap dan nilai-nilai yang mendasarinya. Bermain peran adalah kegiatan bermain dimana anak melakukan kegiatan meniru perilaku. Perilaku ini dapat berupa perilaku manusia, hewan, tanaman dan kejadian. Bermain peran dikenal juga dengan sebutan main pura-pura, khayalan, fantasi, make believe atau simbolis. Pembelajaran berbasis sentra merupakan pembelajaran yang paling mutakhir yang dilaksanakan di lingkungan pendidikan anak usia dini; dengan karakteristik utamanya memberikan pijakan (scaffolding) untuk membangun konsep aturan, ide, dan pengetahuan anak serta konsep densitas dan intensitas bermain. Model pembelajaran ini berfokus pada anak yang dalam proses pembelajarannya berpusat di sentra bermain dan pada saat anak dalam lingkaran.

Pada umumnya pijakan dalam model ini untuk mendukung perkembangan anak, yaitu pijakan setelah bermain. Pijakan ini diberikan untuk mencapai perkembangan yang lebih tinggi. Sentra berasal dari kata "centre" yang artinya "pusat". Setiap sentra memiliki keistimewaannya masing-masing. Menurut Mulyasa (2012: 149) Sentra Main peran adalah sentra yang mengalirkan materi/ knowledge pada anak melalui main peran. Materi knowledge yang dialirkan melalui serangkaian kegiatan yang telah ditata/ diorganisasikan dalam perencanaan pembelajaran yang dibuat guru yang disesuaikan dengan kebutuhan perkembangan anak, semua kegiatan main diarahkan pada satu titik (pusat) yaitu tujuan yang telah direncanakan dalam rencana pembelajaran.

Semua materi/knowledge yang dialirkan pada anak dibingkai oleh tema yang dimaksudkan agar materi/knowledge tersebut tidak tumpang tindih atau tercecer atau materi yang tidak berkaitan ada didalamnya. Tema yang diambil adalah tema yang dekat dengan kehidupan anak (Madyawati, 2012: 18). Sentra main peran, memberi kesempatan pada anak untuk mengembangkan Pengertian mereka tentang dunia sekitarnya melalui peran yang dimainkan, dimulai dari lingkungan yang terdekat mereka yaitu keluarga hingga lingkungan sekitar; sekolah, pasar, rumah sakit, kantor pos, pemadam kebakaran, pantai/ laut, desa (Arriyani, 2010: 21).

Adapun alat dan bahan dalam sentra main peran adalah sebagai berikut: 
a. Main peran besar

1) Alat dan bahan main kerumah tanggaan

2) Alat dan bahan main keprofesian

3) Alat dan bahan main yang mendukung keaksaraan anak.

b. Alat dan bahan main kerumah tanggaan

Direktorat Jenderal Pelayanan dan Rehabilitas Sosial Direktorat Bina Pelayanan Sosial Anak Departemen Sosial RI memiliki standar sosial anak di kelompok bermain (2004: 26), meliputi alat-alat yang ditempatkan pada ruang-ruang yang ada dalam rumah, seperti:

1) Ruang tamu: meja dan kursi tamu, karpet, taplak, vas bunga

2) Ruang keluarga: karpet, meja kecil untuk telepon beserta kertas dan pensil untuk mencatat pesan, rak buku, buku-buku cerita.

3) Ruang tidur: dipan kecil beserta kasur, bantal dan guling, seprei, dan sarung bantal guling.

4) Ruang makan: meja dan kursi makan, perlengkapan makan dan minum, makanan dan minuman pura-pura, loker tempat penyimpanan alat main.

5) Ruang dapur: meja, perlengkapan memasak (seperti: kompor mainan, wajan, sodet/sotil), kain lap, celemek dan lain-lain.

6) Kamar mandi: perlengkapan mandi (sabun, sampo, pasta gigi, dan sikat gigi pura-pura, handuk), bak mandi, keran wastafel, closet.

7) Alat pendukung kebersihan: sapu, kain pel, tempat sampah, vacum cleaner.

c. Alat main keprofesian

1) Nelayan (tema laut): Kapal dari dus beks, kail, jaring untuk menangkap ikan, wadah tangkapan ikan, lampu penerang, bahan bakar kapal, umpan ikan, ikan-ikanan dari karton dan lain-lain.

2) Dokter (tema pekerjaan): Jas dokter warna putih, masker, sarung tangan karet, stetoskop, thermometer, alat pengukur tekanan darah, jarum suntik mainan, timbangan badan, senter kecil, botol-botol dan obat pura-pura, kertas resep, meja dan kursi, tempat tidur. 
3) Palaentolog (tea dinosaurus): area pasir, topi, baju kerja, sepatu, papan, kertas dan alat tulis, pahat, kuas, tulang-tulang sapi, ayam, barang-barang temuan perlengkapan makan dan minum dan lain-lain.

d. Alat/Bahan Main Mendukung Keaksaraan

Meliputi: Kertas, alat-alat tulis (krayon, spidol, pensil) penggaris, penghapus, bukubuku cerita, buku-buku resep, buku telepon, koran, majalah, brosur catalog belanja. Kertas dengan tulisan bagian-bagian scenario misalnya: rumah sakit, Restoran, kantor pos, super market, pantai, pemadam kebakaran dan lain-lain.

Bermain peran dalam pendidikan anak usia dini merupakan usaha untuk memecahkan masalah melalui peragaan, serta langkah-langkah identifikasi masalah, analisis, pemeranan, dan diskusi.

Departemen Pendidikan Nasional Direktorat Jenderal Pendidikan Non Formal dan Informal Direktorat Pendidikan Anak Usia Dini mengenai pedoman penerapan pendekatan beyond center and circle time (BCCT) (2009: 11) memberikan penjelasan bahwa hakikat bermain peran dalam pembelajaran PAUD terletak pada keterlibatan emosional pemeran dan pengamat dalam situasi masalah yang secara nyata dihadapi. Melalui bermain peran dalam pembelajaran, diharapkan anak-anak mampu: (1) mengeksplorasi perasaan-perasaannya; (2) memperoleh wawasan tentang sikap, nilai, dan persepsinya; (3) mengembangkan keterampilan dan sikap dalam memecahkan masalah yang dihadapi; dan (4) mengeksplorasi inti permasalahan yang diperankan melalui berbagai cara.

\section{Teori-Teori Main Peran}

\section{a. Teori Jean Piaget}

Teori ini menyatakan, seorang profesor psikologi dan biologi yang menyatakan bahwa main peran muncul pada anak yang berusia kira-kira satu tahun. Menurut Piaget, main peran dimulai ketika anak melakukan tindakan yang tidak bisa diterapkan dalam kehidupan nyata. Misalnya, seorang anak yang mengaduk-aduk pasir dalam mangkuk dengan sendok dan pura-pura makan dan mengulang-ngulang ingatan yang menyenangkan, seperti melihat susu dan meminumkannya pada boneka.

Pada tahap yang lebih tinggi, anak dapat melakukan banyak adegan yang mewakili satu peristiwa atau kejadian (collective symbolism). Anak melakukan percakapan lisan dengan diri sendiri (idiosyncratic soliloquies) dan selama percakapan itu, ia menciptakan kesepakatan antara kebutuhan segera dari keinginan dan kesadaran rasional dari egonya. 


\section{b. Teori Menurut Vygotsky}

Menurut Vygotsky, melalui main peran anak dapat melebihi tahap perkembangannya saat ini. Imajinasi merupakan sesuatu yang harus dibangun, sebab belum ada dalam kesadaran anak yang masih kecil dan sama sekali tidak ada pada binatang. Sebagai contoh; pada kehidupan nyata, anak yang berusia tiga tahun tentu tidak pandai menyetrika pakaian, namun, ketika main peran anak tersebut bisa melakukan kegiatan menyetrika pakaian, sama seperti yang dilakukan orang dewasa.

Vygotsky juga mengatakan bahwa main peran yang bermutu membutuhkan pengetahuan dan dukungan orang dewasa yang mampu memberi pijakan dalam main anak, memfasilitasi main melalui pertanyaan-pertanyaan yang mendukung dan memperluas pengalaman main anak (zone of proximal development).

\section{c. Teori Menurut Erik Erikson}

Menurut Erik Erikson main peran adalah suatu jalan untuk pengendalian diri terhadap keinginannya. Kemudian, bagaimana anak menghadapi serangan dari luar terhadap egonya. Erik juga melihat bahwa main peran adalah suatu cara bagi anak untuk memahami tuntutan-tuntutan dari luar yang datang setiap hari. Misalnya, anak usia dini ketika melihat pesawat terbang pada waktu itu juga dan berkeinginan menaiki pesawat tersebut. Jika anak usia enam tahun yang melihatnya, tetap ada hasrat untuk menaikinya. Namun, ia mengerti bahwa pesawat tersebut tidak bisa berhenti tiba-tiba. Ada urutan yang harus dilalui untuk dapat menaikinya.

\section{d. Teori Menurut Sara Smilansky}

Dalam teorinya menyatakan bahwa anak yang terlibat main peran dan tidak bertahan main peran dengan anak yang lain, akan memiliki kesulitan disekolah nantinya. Dalam penelitiannya ia menemukan anak yang memiliki sedikit pengalaman main peran terlihat mendapatkan kesulitan dalam merangkai kegiatan dan percakapan mereka. Terlihat kaku tidak luwes, monoton dan mengulang-ulang perilaku, kesulitan dalam mengembangkan sebuah tema, pikiran dan permainan, kesulitan untuk mengaitkan pengalaman-pengalaman yang mereka miliki (Arriyani, 2010: 26-28).

\section{Pembelajaran Sentra Main peran}

Sagala (2010: 61) memberikan definisi pembelajaran ialah membelajarkan siswa menggunakan asas pendidikan maupun teori belajar merupakan penentu utama keberhasilan pendidikan. Pengembangan kurikulum mencakup pengembangan program 
tahunan, program semester, program modul, program mingguan dan harian (Kunandar, 2010: 235).

Selain pendekatan ada juga dikenal model pembelajaran semua itu berfokus pada proses pengajaran, proses pembelajaran, proses belajar mengajar, atau interaksi belajarmengajar. Menurut Sukmadinata, dkk. (2012: 167) pendekatan pembelajaran mempunyai lingkup yang luas, melihat pembelajaran sebagai proses belajar siswa yang sedangberkembang untuk mencapai tujuan perkembangnnya. Dilembaga pendidikan taman kanak-kanak, pengaturan proses belajar mengajar itu didasarkan pada garis-garis besar program kegiatan belajar mengajar (GBPKB) yang telah ditetapkan oleh departemen pendidikan nasional (Bafadal, 2004: 11).

Pembelajaran berbasis sentra merupakan pembelajaran yang paling mutakhir yang dilaksanakan di lingkungan pendidikan anak usia dini; dengan karakteristik utamanya memberikan pijakan (scaffolding) untuk membangun konsep aturan, ide, dan pengetahuan anak serta konsep densitas dan intensitas bermain. Model pembelajaran ini berfokus pada anak yang dalam proses pembelajarannya berpusat di sentra bermain dan pada saat anak dalam lingkaran. Pada umumnya pijakan dalam model ini untuk mendukung perkembangan anak, yaitu pijakan setelah bermain. Pijakan ini diberikan untuk mencapai perkembangan yang lebih tinggi.

Mulyasa (2012: 149) menjelaskan sentra bermain dilengkapi dengan seperangkat alat bermain yang berfungsi sebagai pijakan lingkungan yang diperlukan untuk mendukung perkembangan anak dalam 3 jenis bermain, yaitu bermain sensori motor atau fungsional, bermain peran, dan bermain pembangunan (konstruktif, yaitu membangun pemikiran anak), sedangkan saat lingkaran dilakukan guru untuk memberikan dukungan kepada anak yang dilakukan sebelum dan sesudah bermain. Sentra ada beberapa jenis yakni sentra main peran, sentra bahan alam, sentra musik, sentra persiapan dan sentra balok.

\section{a. Perencanaan Program Pembelajaran Sentra Main Peran}

Perencanaan adalah suatu cara untuk mengantisipasi dan menyeimbangkan perubahan (Uno, 2011: 1). Perencanaan merupakan hasil proses berfikir yang mendalam (Sanjaya, 2008: 25). Program pembelajaran adalah susunan kegiatan yang akan dilakukan selama satu tahun pembelajaran. Direktorat Pendidikan Anak Usia Dini

dalam pedoman tekhnis penyelenggaraan kelompok bermain (2010: 5) ada tiga macam perencanaan kegiatan bermain yaitu perencanaan tahunan, semesteran, perencanaan 
kegiatan bermain mingguan dan harian dan perencanaan persiapan jenis permainan. Direktorat Pembinaan Taman Kanak-kanak dan Sekolah Dasar, Pedoman Pengembangan Silabus (2010: 5) menyatakan perencanaan semester merupakan program pembelajaran yang berisi jaringan tema, bidang pengembangan, tingkat pencapaian perkembangan, capaian perkembangan dan indikator yang ditata secara urut dan sistematis, alokasi waktu yang diperlukan untuk setiap jaringan tema, dan sebarannya kedalam semester 1 (satu) dan 2 (dua).

Perencanaan mingguan merupakan penjabaran dari perencanaan semester. Kegiatan bermain mingguan disusun berdasarkan perencanaan tahunan dan semesteran. Hal-hal yang harus diperhatikan dan ditetapkan meliputi : (1) tema kegiatan (2) kelompok yang akan melakukan kegiatan bermain (3) semester dan tahun ajaran (4) jumlah waktu (5) hari dan tanggal pelaksanaan (6) jam pelaksanaan (7) tujuan kegiatan bermain (8) materi yang akan dimainkan (9) bentuk kegiatan bermain (10) penataan lingkungan (11) bahan dan alat yang diperlukan dalam bermain (12) evaluasi perkembangan anak. Menurut Yuliani, tema digunakan pada pembelajaran anak usia dini untuk membangun pengetahuan pada anak dan mengembangkan seluruh aspek perkembangan.

\section{b. Pelaksanaan Pembelajaran Sentra Main Peran}

Direktorat pendidikan anak usia dini dalam pedoman tekhnis penyelenggaraan kelompok bermain ketika pelaksanaan pembelajaran sentra main peran terdapat empat tahap untuk pijakan pengalaman main yang bermutu untuk mendukung perkembangan anak. Pemberian pijakan merupakan implikasi praktis dari teori kognitif vygotsky, antara lain menyebutkan bahwa tingkat perkembangan intelektual yang tertinggi pada anak terjadi saat anak berinteraksi dengan orang dewasa atau anak lain yang lebih tinggi kemampuannya (Asmawati, 2020: 813). Pijakan-pijakan tersebut pijakan lingkungan main, pijakan sebelum main, pijakan selama main, dan pijakan setelah main. Adapun urutan dalam pelaksanaan pembelajaran sentra main peran.

1) Penataan lingkungan main sebelum anak datang pendidik menyiapkan bahan dan alat main yang akan digunakan sesuai dengan rencana belajar dan kelompok anak yang akan dibina. Penataan main sesuai dengan tujuan yang dicapai selama bermain. 
2) penyambutan anak guru menyambut anak, kemudian anak diarahkan untuk main bebas bersama teman-teman lain.

3) main pembukaan (pengalaman gerakan kasar) pendidik menyiapkan seluruh anak dalam lingkaran, kemudian dilanjutkan dengan kegiatan pembuka, seperti permain tradisional, gerak dan musik.

4) Transisi 10 menit kegiatan ini bertujuan supaya anak tenang dengan cara bernyanyi dalam bentuk lingkaran. Pada masa ini, anak diberi kesempatan untuk kekamar kecil, pembiasaan kebersihan diri, dan minum.

\section{Prosedur Kerja Guru di Sentra Main Peran}

\section{a. Persiapan Guru/ Pijakan Sebelum Main}

Langkah pertama yang harus disiapkan seorang guru dalam pelaksaan main peran adalah persiapan sebelum main. Persiapan sebelum main dilakukan dengan pengaturan waktunya lebih kurang 15 menit sesuai arahan yang telah dibuat oleh guru sentra dan sebelum main guru sentra memastikan penataan sudah sesuai dengan yang diharapkan. Guru harus memastikan rencana pembelajaran yang telah disusun dapat memenuhi kebutuhan dari setiap anak yang akan datang ke sentra main peran dan ia juga mampu mengembangkan tingkatan tahap perkembangan untuk setiap anak.

\section{b. Penataan Lingkungan Main}

Penataan lingkungan main peran merupakan bagian penting dalam kegiatan belajar dan mengajar. Arriyani (2010: 60) menjelaskan penataan lingkungan main peran yang bermutu harus dapat mengembangkan seluruh perkembangan anak yang menjadi tujuan sentra yaitu dapat membangun seluruh domain perkembangan berfikir anak, membangun Sembilan kecerdasan, dan nilai-nilai 18 sikap dari semua anak yang datang ke sentra.

Main peran dapat dilakukan baik didalam maupun diluar ruangan. Penataan lingkungan main untuk keduanya harus merujuk pada tujuan perencanaan pembelajaran yang sudah dibuat oleh guru, pelaksanaan main peran diluar dapat dilakukan sesuai dengan kebutuhan dan tergantung pada faktor cuaca. Penataan lingkungan main yang bermutu dan kaya disentra juga harus mendukung perkembangan anak melalui tiga jenis main; main sensori motor, main simbolik, dan main pembangunan. Idealnya luas tempat main peran untuk setiap anak disentra minimal tujuh meter persegi, bila terdapat sepuluh anak main 
di sentra main peran, maka luas tempat yang harus disediakan adalah tujuh puluh meter persegi.

Penataan lingkungan main disentra main peran dapat meningkatkan kemampuan berfikir anak, daya imaginasi berupa ide/gagasan yang muncul saat pertama kali anak masuk dan melihat kedalamnya, akan melakukan apa selama kegiatan main berlangsung nanti.

\section{c. Pijakan Awal Main}

Menyambut dan mengajak anak untuk berkumpul ditempat yang telah disiapkan, mengucapkan salam, menggunakan berbagai cara seperti bernyanyi untuk mengambil perhatian anak. Mengalirkan materi dengan berbagai macam kegiatan seperti diskusi, menggunakan alat pendukung yang telah disiapkan, memperlihatkan gambar-gambar dari buku atau poster, mengenalkan peran-peran yang akan dimainkan melalui skenario main.

Memastikan anak sudah mengerti akan main apa nantinya dengan panduan pertanyaan, seperti "siapa yang akan mengurus hewan ternak di kandang nanti? "Apa yang akan diberikan pak tani untuk ternaknya makan? "atau "Apa saja pekerjaan pak tani ?" (main peran besar).

Memperagakan bagaiman cara menggunakan boneka-boneka dan alat-alat lainnya yang akan dimainkan (main peran kecil). Memberi kesempatan pada anak untuk memilih peran, memastikan semua anak sudah menetapkan peran yang akan dimainkan (Soefandi, dkk, 2009: 64).

Mendiskusikan aturan main untuk kelancaran dan kenyamanan main, antara lain :

1) Fokus, main sesuai peran

2) Kontrol diri

3) dalam berinteraksi dengan pemeran lain dalam menggunakan alat main

4) Beres-beres, selesai bermain kembalikan alat ketempatnya (sesuai label pada tempatnya).

\section{d. Pijakan Saat Main}

Saat kegiatan main berlangsung, guru bergerak bebas diantara anak. Mengamati anak bermain, membuat catatan perkembangan yang ditampilkan anak, saat berada 
disekitar anak, guru memposisikan dirinya dapat mengamati keseluruhan anak tetapi tidak mengganggu dinamika gerak anak main.

Mencatat kegiatan pertama yang dilakukan anak, peran apa yang diambil anak pertama main merupakan informasi bagi guru tentang pemahaman anak melalui peran yang dipilihnya. Pengembangan kemampuan main peran anak juga terdukung dengan pengetahuan guru dan kepekaan guru dalam memberikan dukungan dalam pendampingannya selama anak main, kapan ia "masuk" kapan ia "keluar".

\section{e. Pijakan Akhir/ Beres-beres}

Direktorat Pendidikan Anak Usia Dini, pedoman penerapan pendekatan beyond center and circle time (bcct) (2009: 12) menjelaskan kegiatan beres-beres merupakan bagian terpenting kegaiatan sentra, saat-saat yang tepat dalam mendukung membangun semua domain perkembangan anak (estetik, afeksi, kognisi, bahasa, psikomotor, dan sosial), diakhir kegiatan main.

\section{KESIMPULAN}

Bermain peran adalah kegiatan bermain dimana anak melakukan kegiatan meniru perilaku. Perilaku ini dapat berupa perilaku manusia, hewan, tanaman dan kejadian. Adapun teori-teori bermain peran terdiri dari teori Jean Piaget, Vygotsky, Erik Erikson dan teroti Sara Smilansky. Adapun dalam sentra bermain peran yang harus diperhatikan terdiri dari: perencanaan program pembelajaran sentra main peran, pelaksanaan pembelajaran sentra main peran, prosedur kerja guru di sentra main peran.

\section{DAFTAR PUSTAKA}

Asmawati Luluk dkk. 2010. Pengelolaan Kegiatan Pengembangan Anak Usia Dini, Universitas Terbuka.

Arriyani Neni,Wismiarti. 2010. Panduan Pendidikan Sentra Main Peran, Jakarta: Sekolah Al-falah.

Bafadal Ibrahim. 2004. Dasar-Dasar Manajemen Dan Supervisi Taman Kanak-Kanak, Jakarta: Bumi Aksara.

B Uno Hamzah. 2011. Perencanaan Pembelajaran, Jakarta: Bumi Aksara.

Dokumentasi Pedoman Bahan Ajar TK Al-Muthmainnah Sentra Main Peran Kota Jambi, Tanggal 15 Februari 2020

21 | ZURIAH : Jurnal Pendidikan Anak Usia Dini, Vol. 1 No. 1, Mei 2020 
Direktorat Jenderal Pelayanan dan Rehabilitas Sosial Direktorat Bina Pelayanan Sosial Anak Departemen Sosial RI. 2004. Standar Sosial Anak di Kelompok Bermain.

Departemen Pendidikan Nasional Direktorat Jenderal Pendidikan Non Formal Dan Informal Direktorat Pendidikan Anak Usia Dini. 2009. Pedoman Penerapan Pendekatan Beyond Center And Circle Time (BCCT), Jakarta: Depdiknas.

Direktorat Pendidikan Anak Usia Dini. 2010. Pedoman Tekhnis Penyelenggaraan kelompok Bermain, Jakarta.

Direktorat Pembinaan Taman Kanak-kanak dan Sekolah Dasar. 2010. Pedoman Pengembangan Silabus, Jakarta.

Direktorat Pendidikan Anak Usia Dini. 2010. Pedoman Tekhnis Penyelenggaraan Kelompok Bermain. H.E Mulyasa. 2012. Manajemen PAUD, Bandung: PT Remaja Rosdakarya.

Indra soefandi, S. Ahmad pramudya. 2009. Strategi mengembangkan Potensi Kecerdasan Anak.

Jakarta: Bee Media.

Madyawati, Lilis. 2012. Permainan Dan Bermain Anak, Jakarta: Prenada Media Group.

Sagala Syaiful. 2010. Konsep dan Makna Pembelajaran, Bandung: Alfabeta.

Sanjaya Wina. 2008. Perencanaan Dan Desain Sistem Pembelajaran, Jakarta: Kencana Prenada Media Group.

Sukmadinata Nana Syaodih Dan Erliana Syaodih. 2012. Kurikulum dan Pembelajaran Kompetensi, Bandung: Refika Aditama.

Kunandar. 2010. Guru Profesional, Jakarta: Raja Grafindo Persada. 